\title{
Long-Term Outcomes of in Utero Ramadan Exposure: A Systematic Literature Review
}

 \\ Olaf Horstick $^{1}(\mathbb{D})$, Peter Dambach ${ }^{1}\left(\mathbb{D}\right.$, Stefan Kohler ${ }^{1}(\mathbb{D})$ and Volker Winkler ${ }^{1, *(\mathbb{D})}$ \\ 1 Heidelberg Institute of Global Health, Heidelberg University Hospital, Im Neuenheimer Feld 130.3, \\ 69120 Heidelberg, Germany; melani.mahanani@uni-heidelberg.de (M.R.M.); \\ eman.abderbwih@uni-heidelberg.de (E.A.); a.deckert@uni-heidelberg.de (A.D.); \\ khatia.antia@uni-heidelberg.de (K.A.); Olaf.Horstick@uni-heidelberg.de (O.H.); \\ peter.dambach@uni-heidelberg.de (P.D.); stefan.kohler@uni-heidelberg.de (S.K.) \\ 2 Potsdam Institute for Climate Impact Research, Member of the Leibniz Association, P.O. Box 601203, \\ 14412 Potsdam, Germany; wendt@pik-potsdam.de \\ * Correspondence: volker.winkler@uni-heidelberg.de; Tel.: +49-6221-56-5031
}

Citation: Mahanani, M.R.;

Abderbwih, E.; Wendt, A.S.; Deckert, A.; Antia, K.; Horstick, O.; Dambach, P.; Kohler, S.; Winkler, V. Long-Term Outcomes of in Utero Ramadan Exposure: A Systematic Literature Review. Nutrients 2021, 13, 4511. https://doi.org/10.3390/nu13124511

Academic Editor: Sara Della Torre

Received: 30 November 2021

Accepted: 15 December 2021

Published: 17 December 2021

Publisher's Note: MDPI stays neutral with regard to jurisdictional claims in published maps and institutional affiliations.

Copyright: (c) 2021 by the authors. Licensee MDPI, Basel, Switzerland. This article is an open access article distributed under the terms and conditions of the Creative Commons Attribution (CC BY) license (https:// creativecommons.org/licenses/by/ $4.0 /)$.

\begin{abstract}
Health outcomes of in utero Ramadan exposure have been reported in a systematic literature review; however, the available literature on long-term effects were not fully covered. Our study aims to specifically review the long-term outcomes of in utero Ramadan exposure. We searched for original research articles analyzing any long-term outcome of in utero Ramadan exposure, excluding maternal and perinatal outcomes. Sixteen studies from 8304 non-duplicate search results were included. Most studies suggest negative consequences from in utero Ramadan exposure on health, as well as on economic outcomes later in adulthood. Higher under-five mortality rate, higher mortality under three months, and under one year, shorter stature, lower body mass index, increased incidence of vision, hearing and learning disabilities, lower mathematics, writing and reading scores, as well as a lower probability to own a home were associated with Ramadan exposure during conception or the first trimester of pregnancy. Furthermore, age and sex seem to play a pivotal role on the association. Existing studies suggest that in utero Ramadan exposure may adversely impact long-term health and economic well-being. However, evidence is limited. Meanwhile, increasing awareness of the potential risks of Ramadan fasting during pregnancy should be raised among pregnant women and clinicians and other antenatal care workers should promote better maternal healthcare.
\end{abstract}

Keywords: Ramadan; in utero; pregnancy; systematic review

\section{Introduction}

During Ramadan, healthy Muslim adults are obliged to fast from dawn until sunset, abstaining from food, drink, medicine, and sexual activity. Not only is the timing of meals altered during the Ramadan period, but the type of food eaten, as well as sleeping and behavioral patterns, are substantially changed for about 4 weeks [1]. Improvements in dietary diversity during Ramadan were found even when Muslims did not adhere to fasting [2]. A growing body of evidence has identified direct and indirect health effects of Ramadan fasting in adults, such as changes in lipid, carbohydrate, protein, and hormone metabolisms, as well as in body weight [1,3,4]. Individuals' moods and irritability also appear to change during Ramadan, which has been associated with restricted nicotine use and reductions in sleep [5]. Overall, health effects among Ramadan fasting adults have been described as manageable or even beneficial $[1,6]$.

In contrast, the effects of Ramadan on the unborn child are less explored. Even though Islamic law gives permission for pregnant women to opt out of fasting, it is common that expectant mothers follow Ramadan fasting due to different reasons, such as to improve 
their spiritual activity [7], as well as due to influence from partners and families [8,9]. It is widely perceived that the early phase of pregnancy, when organogenesis takes place, is crucial for human development [10]. During the first trimester, when the immune system, endocrine and metabolic pathways develop, the fetus may be particularly prone to effects from Ramadan fasting, such as short-term undernutrition [10,11]. An analysis of in utero Ramadan exposure as a natural experiment showed a significantly elevated mortality among children under five [12]. In principle, a natural experiment makes use of an individual's assignment to the experimental and control conditions by nature or by other factors outside the control of the investigators. However, a systematic literature review on the perinatal outcomes of Ramadan fasting during pregnancy was inconclusive [13].

In contrast to short-term outcomes, our study aimed to collect and evaluate existing evidence on the relationship between in utero Ramadan exposure and its long-term effects, excluding perinatal and maternal outcomes. A recent systematic review by Oosterwijk et al. [14] analyzed the impact of Ramadan exposure on health, including long-term effects, and concluded that no study reported significant long-term effects. However, the systematic review included only part of the available literature, and focused on health only.

Long-term effects of in utero famine have been well studied and showed an increased risk for obesity, diabetes, coronary heart disease, breast cancer and cognitive decline later in life [15-17]. Ramadan fasting is less dramatic than famine; however, it may have effects on the developing fetus later in life.

\section{Materials and Methods}

This systematic review was conducted in accordance with the Preferred Reporting Items for Systematic Reviews and Meta-Analyses (PRISMA) 2009 guidelines (see Table S3) [18]. Two authors (M.R.M. and E.A.) independently performed the literature search, screened the titles and abstracts, assessed the full texts, and performed the data extraction and quality assessment. Any arising disagreement was solved by discussion among all authors until consensus was reached.

We searched the scientific literature utilizing the following databases from inception to 21 November 2021: PubMed, PsycINFO, EconLit, Index Islamicus, Web of Science, Cochrane Library, WHO Global Index Medicus, WHO Virtual Health Library, and Google Scholar. The searches were performed very broadly, using only the term "Ramadan", which covers all common variations of Ramadan fasting because they all include this term. We included only original research articles that mainly assessed the long-term outcomes of in utero Ramadan exposure, and excluded studies reporting on either maternal or fetal outcomes. For Google Scholar, we modified the search strategy by screening 50 results stepwise after the first 200 records, until no further relevant studies were found. After identifying eligible articles, we searched their reference lists for additional papers. Full search strategy for all databases can be found in Table S1.

We used the standardized data collection form of the Cochrane Collaboration Public Health Group [19] to extract the following information from each study: authors, publication date and journal, country, type of study, aims and objectives, sampling techniques and dates of data collection, sample size and age and sex of participants, exposures and outcomes including outcome measures, key conclusions, limitations and recommendations.

Afterwards, we used the Specialist Unit for Review Evidence (SURE) tools [20] to assess the quality of included studies (see Table S2). Specifically, we applied the tool for cohort studies, which consists of the following 13 items: study design, research question, setting and location, participant selection, participant characteristics, exposures and outcomes measurement, bias consideration, study size, statistical methods, participant flow, results, sponsorship/conflict of interest and limitations.

We analyzed studies according to the following information: outcome measures, age, and sex of the population of interest. Considering the limited number of studies and a variety of outcome measures, we decided to forgo a meta-analysis. 


\section{Results}

We identified a total of 8690 original research articles, of which 8304 remained after the removal of duplicates from the search results. Based on title and abstract screening, 8280 studies were excluded because they mostly focused on maternal or perinatal outcomes or on fasting adults. We screened the full text of 24 studies, of which 16 met the inclusion criteria (see Figure 1). Three studies were excluded because they did not present original research (commentaries), three focused on short-term consequences, one focused on the impact of religion adherence, and two studies were published twice in different journals with different titles; therefore, we only kept the primary publication.


Figure 1. PRISMA flow diagram depicting the process of study selection for systematic review.

\subsection{Study Characteristics}

Six studies were conducted in South East Asia (all in Indonesia) [21-26], one in South Asia (Pakistan) [27], two in Eastern Mediterranean region (Iran) [28,29], two in Africa (one in Burkina Faso [12] and one in Ethiopia [30]) and three in Europe (one in England [31] and 
two in Denmark [32,33]). Two studies had a cross-regional focus including 39 countries in Eastern Europe, Africa, Eastern Mediterranean, Asia, and North America [34,35].

All studies used retrospective longitudinal data for analysis. Six manuscripts used nationally representative data from the Indonesian Family Life Survey (IFLS) [21-25]; one used data from the district-based Punjab Multiple Indicator Survey (MICS) [27]; two used school register data [28,31]; one used data from the Urban Health Equity and Assessment Response Tool (Urban HEART) [29]; two used Danish administrative records [32,33]; one study used Michigan (United States) natality data and census data for Iraq and Uganda [34]; one used data from the Nouna Health and Demographic Surveillance System in northwestern Burkina Faso [12]; one used data from the Ethiopia Demographic and Health Survey [30]; and one analyzed data collected from 98 demographic and health surveys [35].

Studies investigated the children of Muslim parents [21,23,30,32-34], children of Ramadan-exposed Muslim mothers (experiencing Ramadan during pregnancy, with unknown fasting status) [21,22,24-27,29,31,35], and children of Ramadan fasting mothers [28]. All studies included non-exposed control groups represented by children of non-Muslim parents $[21,23,30,32-34]$, children of non-exposed mothers (no Ramadan during pregnancy) $[21,22,24-27,29,31,35]$, and children of non-fasting Muslim mothers [28]. Most studies targeted more than one age group, although some others targeted only children $[27,29,31]$, adolescents [32], and adults [22,34].

Most studies [12,21-27,29-31,33-35] used an intention-to-treat design by estimating the Ramadan exposure based on an individual's date of birth, calculating if Ramadan overlapped with the pregnancy, assuming a full-term birth (individual's mother's fasting status unknown). One study used questionnaire data asking mothers about fasting throughout their pregnancies, defining in utero Ramadan exposure as fasting for at least 27 days during pregnancy [28]. Another study defined in utero Ramadan exposure as when the mother and the child had immigrated from a country with a more than $90 \%$ Muslim population (individual's fasting status unknown) [32]. Some studies highlighted that their study design allowed them to analyze Ramadan exposure during pregnancy as a natural experiment, indicating the possibility for causal inference [12,21,24,25,28,31-33].

Standardized tools for anthropometric measurements assessed by trained nurses in other studies included height-for-age z-scores [26,27,29,35], weight-for-age z-scores [26,30], and body-mass-index-for-age z-scores [26]. The Wechsler Intelligence Scale for ChildrenRevised (WISC-R) and the Wechsler Preschool and Primary Scales of Intelligence (WPPSI), conducted by two randomly assigned persons that did not know the exposure condition, were used to estimate individual's intelligence quotient [28]. One study used self-reported information on breathing difficulties, and respondents were asked to indicate whether they had experienced wheezing or shortness of breath during the 4 weeks before the interview [21]. Another study took measurements of a diverse set of health variables such as weight, height, blood pressure, pulse, lung capacity, and hemoglobin level by nurses and applied the Nine-point General Health Scale for measuring general health by other health professionals. This study also used self-reported information on chest pain and slow-healing wounds [23]. One study used teacher assessment scores on the subjects of mathematics, reading, and writing [31]. A Danish study used standardized test scores from the national exams on the subjects of Danish, English, mathematics, and science administered by the Ministry of Education [32]. Two studies used the Raven's Colored Progressive Matrices (CPM) for evaluating cognitive ability, i.e., general intelligence, without giving detailed information about the outcome assessment [24,25]. The same studies used data on mathematics scores, earnings, hours worked, employment, and child labor from household interviews, whereas the employment indicator, salary income, and annual hours were based on official reports by employers [24,25]. One study examined the educational attainment: whether a child whose age was between 7 and 11 was currently enrolled in a primary school, and whether a child whose age was between 15 and 20 had graduated from a primary school [30]. The wage was calculated on the basis of salary income divided by hours of work in that year [33]. One study used data on disability, home ownership, 
and employment status from National Censuses without further information regarding the outcome assessment [34].

Most authors conducted descriptive analysis to compare health and other outcomes between the exposed and non-exposed groups by calculating percentages, means with standard deviation (SD), 95\% confidence intervals (95\% CIs) and $p$-values. For further analyses, bivariable and multivariable models were performed, utilizing quantile regression [24], logistic regression [21,26,27,31,32], linear regression (OLS) $[22,23,25,28-30]$ and kernelweighted local polynomial regressions [35]. In most studies with a natural experiment design, difference-in-differences analyses (DID) [21,31-34] were performed.

Table 1 summarizes the main characteristics of all included studies, along with the quality assessment.

\subsection{Study Results According to Outcome Measures}

Table 2 provides an overview of results presenting all outcomes with statistical measures.

\subsection{Health Outcomes}

Adult Muslims who had been in utero during Ramadan were thinner and had a smaller stature than Muslims who had not, whereas among non-Muslims, no differences were found [22]. In line with these findings, another study showed that children born to religious Muslim mothers and exposed to Ramadan in the first trimester of pregnancy were shorter in late adolescence (15-19 years of age) compared with their unexposed siblings. Lower BMI was also observed and peaked in early adolescence (10-14 years of age) for exposed Muslim children in comparison to their unexposed siblings [26]. One study concluded, on the one hand, that under-five children exposed to in utero Ramadan were more likely to be stunted if the exposure happened in any month of gestation prior to the eighth month of pregnancy. On the other hand, children under five who were exposed to in utero Ramadan in the ninth month were taller and heavier than non-exposed children [27]. Another study supported this finding, showing that in utero Ramadan exposure was associated with decreases in children's height at ages of 10 years or older [29]. In a crossregional study of 37 countries, Ramadan exposure during early and mid-gestation affected the height of 3- and 4-year-old male Muslim children, and the effect tended to be stronger in West Africa, Central Asia, and other countries with a higher proportion of Muslims in the population. Effects on height in female children were not detected consistently [35].

When compared with children of non-Muslim mothers, the mortality under three months and mortality under one year of children born to Muslim mothers were higher when Ramadan occurred during the first trimester [30]. Similarly, another study found that the under-five mortality rates of children born to Muslim mothers were higher when Ramadan occurred during conception, and the first and second trimesters [12]. Vision, hearing, and learning disability incidence increased among Muslim adults when Ramadan occurred during the first month of pregnancy [34]. Using the WPPSI for children aged 4 to 6 and the WISC-R for those aged 6 and 13, fasting during pregnancy had no effect on the intellectual development [28]. In contrast, a study that analyzed Pakistani and Bangladeshi immigrants in England using student register data found that test scores on the mathematics, reading, and writing abilities of 7-year-old children were lower when exposed to Ramadan in early pregnancy [31]. Similarly, in Indonesia, another study identified lower scores on Raven's CPM tests and lower mathematics scores among 8- to 15-year-old children who were in utero during Ramadan [24]. Using standard test scores drawn from Danish administrative records, a study showed that fetal exposure to Ramadan had a negative impact on the academic proficiency of Muslim students (aged 16 years), especially females [32]. In line with these findings, one study assessed that children exposed to Ramadan in utero scored lower on Raven's CPM tests and on mathematics tests [25] than unexposed children. 


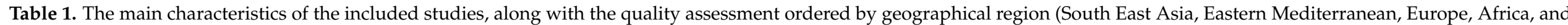
cross-regional).

\begin{tabular}{|c|c|c|c|c|c|c|c|}
\hline Country & $\begin{array}{l}\text { Author, Year of } \\
\text { Publication }\end{array}$ & Year of Data Collection & Age & Sample & $\begin{array}{l}\text { Exposure Estimation (in } \\
\text { Utero Ramadan } \\
\text { Exposure) Based on }\end{array}$ & $\begin{array}{l}\text { Outcome Measures } \\
\text { Including Results }\end{array}$ & $\begin{array}{l}\text { Quality Assessment } \\
\text { Score (Max. 13) }\end{array}$ \\
\hline Indonesia & $\begin{array}{c}\text { Pradella and van Ewijk, } \\
2018[21]\end{array}$ & 1997-2008 & $\geq 15$ & 28,489 & date of birth & $\begin{array}{l}\text { wheezing } \leftrightarrow, \\
\text { breathing difficulty } \downarrow\end{array}$ & 11 \\
\hline Indonesia & van Ewijk et al., 2013 [22] & 2000 & $\geq 18$ & 43,649 & date of birth & height $\downarrow$, weight $\downarrow$, BMI $\downarrow$ & 11 \\
\hline Indonesia & Van Ewijk, 2011 [23] & 2000 & $\geq 18$ & 29,695 & date of birth & $\begin{array}{c}\text { measurements of physical } \\
\text { condition (nine-point general } \\
\text { health scale) } \downarrow \text {, blood pressure } \\
\leftrightarrow \text {, pulse } \downarrow \text {, hemoglobin level } \\
\leftrightarrow \text {, risk of slow-healing } \\
\text { wounds } \downarrow \text {, chest pain } \downarrow\end{array}$ & 8 \\
\hline Indonesia & Majid et al., 2019 [24] & 1993 and 2007 & $8-15,18-65$ & $\begin{array}{l}\text { Raven's CPM: } 3514, \\
\text { score: } 3521, \text { hours } \\
\text { worked: } 7780, \\
\text { earnings: } 6438\end{array}$ & date of birth & $\begin{array}{c}\text { Raven's Colored Progressive } \\
\text { Matrices (CPM) } \downarrow \text { and } \\
\text { mathematics score } \downarrow \text { (age } \\
\text { 8-15); mean hours worked } \downarrow \\
\text { and earnings } \leftrightarrow \text { (age 18-65) }\end{array}$ & 12 \\
\hline Indonesia & $\begin{array}{l}\text { Kunto and Mandemakers, } \\
2019[26]\end{array}$ & $\begin{array}{c}\text { 1993/1994, 1997/1998, } \\
\text { 2000, 2007/2008, and } \\
\text { 2014/2015. }\end{array}$ & 0-19 & 45,246 & date of birth & $\begin{array}{c}\text { height-for-age Z-scores }{ }^{\mathrm{T}} \downarrow \text {, } \\
\text { weight-for-age Z-scores } \leftrightarrow \text {, } \\
\text { body-mass-index-for-age } \\
\text { Z-scores }{ }^{\mathrm{T}} \leftrightarrow\end{array}$ & 11 \\
\hline Indonesia & Majid, 2015 [25] & 1993, 1997, 2000, 2007 & $6-14,21-29$ & 19,038 & date of birth & $\begin{array}{c}\text { Raven's CPM } \downarrow \text { and } \\
\text { mathematics score } \downarrow \text { (age } \\
\text { 6-14); mean hours worked } \downarrow \\
\text { and employment } \downarrow \\
\text { (age 21-29); child labor } \downarrow\end{array}$ & 9 \\
\hline Pakistan & $\begin{array}{c}\text { Chaudhry and Mir, } \\
2021 \text { [27] }\end{array}$ & $\begin{array}{l}\text { 2007-2008, 2010-2011, } \\
\text { 2013-2014, 2017-2018 }\end{array}$ & $0-5$ & 179,943 & date of birth & height-for-age Z-scores ${ }^{\mathrm{T}} \downarrow$ & 12 \\
\hline Iran & Azizi et al., 2004 [28] & 2001 & $4-13$ & 191 & $\begin{array}{l}\text { mothers who fasted } \\
\text { during Ramadan } \\
\text { (questionnaire) }\end{array}$ & IQ score $\leftrightarrow$ & 8 \\
\hline Iran & Karimi et al., 2021 [29] & 2011 & $0-18$ & 96,114 & date of birth & height-for-age Z-scores ${ }^{\mathrm{T}} \leftrightarrow$ & 10 \\
\hline England & Almond et al., 2011 [31] & 2002 & 7 & NA & date of birth & $\begin{array}{l}\text { test score on mathematics }{ }^{\mathrm{T}} \downarrow \text {, } \\
\quad \text { reading }{ }^{\mathrm{T}} \downarrow \text {, writing }{ }^{\mathrm{T}} \downarrow\end{array}$ & 9 \\
\hline
\end{tabular}


Table 1. Cont.

\begin{tabular}{|c|c|c|c|c|c|c|c|}
\hline Country & $\begin{array}{l}\text { Author, Year of } \\
\text { Publication }\end{array}$ & Year of Data Collection & Age & Sample & $\begin{array}{l}\text { Exposure Estimation (in } \\
\text { Utero Ramadan } \\
\text { Exposure) Based on }\end{array}$ & $\begin{array}{l}\text { Outcome Measures } \\
\text { Including Results }\end{array}$ & $\begin{array}{l}\text { Quality Assessment } \\
\text { Score (Max. 13) }\end{array}$ \\
\hline Denmark & Greve et al., 2017 [32] & 1985-1995 & 16 & NA & $\begin{array}{l}\text { mothers and children } \\
\text { immigrated from a } \\
\text { Muslim country } \\
\text { ( } \geq 90 \% \text { Muslims })\end{array}$ & $\begin{array}{l}\text { test score on Danish } \mathrm{T}^{\mathrm{T}} \leftrightarrow \text {, } \\
\text { English } \mathrm{T}^{\mathrm{T}} \leftrightarrow \text {, mathematics } \\
\qquad \mathrm{T}^{\mathrm{T}} \leftrightarrow \text {, science }^{\mathrm{T}} \leftrightarrow\end{array}$ & 9 \\
\hline Denmark & $\begin{array}{l}\text { Schultz-Nielsen et al., } \\
2016 \text { [33] }\end{array}$ & 2008 & $24-55$ & 38,637 & date of birth & $\begin{array}{c}\text { employment }{ }^{\mathrm{T}} \downarrow \text {, annual } \\
\text { salary } \mathrm{T}^{\mathrm{T}} \leftrightarrow \text {, hourly wage rate } \\
{ }^{\mathrm{T}} \leftrightarrow, \text { hours of work }{ }^{\mathrm{T}} \leftrightarrow\end{array}$ & 9 \\
\hline Ethiopia & Lee et al., 2020 [30] & 2000, 2005, 2011 & $0-4,7-11,15-20$ & 21,425 & month of birth & $\begin{array}{c}\text { mortality rate under three } \\
\text { months }{ }^{\mathrm{T}} \downarrow \text {, mortality rate } \\
\text { under one year }{ }^{\mathrm{T}} \downarrow \\
\text { underweight } \\
\mathrm{T}^{\mathrm{T}} \leftrightarrow \text {, anemia } \\
\mathrm{T} \leftrightarrow(\text { age } 0-4) \text {; currently } \\
\text { enrolled in a school }{ }^{\mathrm{T}} \leftrightarrow \\
\text { (age } 7-11 \text { ); graduated primary } \\
\text { school }{ }^{\mathrm{T}} \leftrightarrow \text { (age } 15-20 \text { ) }\end{array}$ & 11 \\
\hline $\begin{array}{l}\text { USA, Iraq, } \\
\text { Uganda }\end{array}$ & $\begin{array}{c}\text { Almond and Mazumder, } \\
2011[34]\end{array}$ & 1989-2006 & $\begin{array}{l}\text { Iraq: } 20-39 \\
\text { Uganda: } 20-80\end{array}$ & $\begin{array}{l}\text { Iraq: } 250,000+, \\
\text { Uganda: } 80,000\end{array}$ & date of birth & $\begin{array}{c}\text { disability }{ }^{\mathrm{T}} \downarrow \text {, home } \\
\text { ownership } \\
\text { employment }{ }^{\mathrm{T}} \downarrow^{\mathrm{T}} \leftrightarrow\end{array}$ & 9 \\
\hline International & $\begin{array}{l}\text { Karimi and Basu, } \\
2018 \text { [35] }\end{array}$ & Varied across countries & $3-4$ & 308,879 & date of birth & height-for-age Z-scores $\downarrow$ & 9 \\
\hline
\end{tabular}

NA: not available; Reported association indicated upon $p<0.05$ : $\downarrow$ : disadvantageous, $\leftrightarrow$ : no association; ${ }^{\mathrm{T}}$ : trimester specific. 
Table 2. Study results according to outcome measures.

\begin{tabular}{|c|c|}
\hline Outcome Measures among Exposed Group & Study Results \\
\hline \multicolumn{2}{|l|}{ Health outcomes } \\
\hline Body mass index (BMI) & $\begin{array}{l}\text { Age-adjusted BMI difference }(\Delta):-0.32,95 \% \text { CI: }-0.57,-0.06 \text { [22] } \\
\qquad \text { BMI } \Delta:-0.094 \text { SD }, p<0.10^{\mathrm{T} 3}[26]\end{array}$ \\
\hline Height & $\begin{array}{c}\text { Age-adjusted height } \Delta:-0.80 \mathrm{~cm}, 95 \% \mathrm{CI}:-1.33,-0.26[22] \\
\text { Height-for-age Z-score } \Delta:-0.105 \mathrm{SD}, p<0.05^{\mathrm{T} 1}[26] \\
\text { Height-for-age Z-score Odds ratio: } 1.225, p<0.001 \mathrm{~T} 2[27] \\
\text { Height-for-age Z-score } \Delta:-0.091 \mathrm{SD}, p<0.01^{\mathrm{T} 2}[29] \\
\text { Height-for-age Z-score } \Delta \text { : girls: } 0.019, p=0.613 ; \text { boys: }-0.073, p=0.001 \text { [35] }\end{array}$ \\
\hline Weight & $\begin{array}{c}\text { Age-adjusted weight } \Delta:-0.85 \mathrm{~kg}, 95 \% \mathrm{CI}:-1.54,-0.17 \text { [22] } \\
\text { Weight-for-age Z-score } \Delta:-0.387 \mathrm{SD}, p<0.05[26] \\
\text { Age-adjusted weight } \Delta:-0.014, p>0.10^{\mathrm{T} 1}[30]\end{array}$ \\
\hline Disability & $\begin{array}{c}\text { General disability: DID coefficient: } 0.819, p<0.05^{\mathrm{T} 0}[34] \\
\text { Vision: DID coefficient: } 0.349, p<0.10^{\mathrm{T} 0}[34] \\
\text { Hearing: DID coefficient: } 0.243, p<0.05^{\mathrm{T} 0}[34] \\
\text { Learning: DID coefficient: } 0.250, p<0.001^{\mathrm{T} 0}[34]\end{array}$ \\
\hline IQ scores & Mean crude full-scale IQ scores: exposed $111 \pm 10$, unexposed $112 \pm 10[28]$ \\
\hline Test scores & $\begin{array}{c}\text { Mathematics } \Delta \text { : girls: }-0.086,95 \% \mathrm{CI}:-0.158,-0.013 \text { [24] } \\
\text { Mathematics } \Delta: \text { boys: }-0.085,95 \% \mathrm{CI}:-0.151,-0.019[24] \\
\text { Mathematics } \Delta:-0.084, p<0.01[25] \\
\text { DID coefficient }-0.054, p<0.05^{\mathrm{T} 1}[31] \\
\text { DID coefficient }-0.022, p>0.10^{\mathrm{T} 0}[32] \\
\text { Reading: DID coefficient }-0.049, p<0.05^{\mathrm{T} 0}[31] \\
\text { Writing: DID coefficient }-0.051, p<0.05^{\mathrm{T} 0}[31] \\
\text { English: DID coefficient }-0.021, p>0.10^{\mathrm{T} 0}[32] \\
\text { Raven's CPM tests: girls: }-0.092,95 \% \mathrm{CI}:-0.150,-0.03[24] \\
\text { Raven's CPM tests: boys: }-0.056,95 \% \mathrm{CI}:-0.109,-0.004[24] \\
\text { Raven's CPM tests: }-7.4 \%, p<0.01[25] \\
\text { Danish: DID coefficient }-0.008, p>0.10^{\mathrm{T} 0}[32] \\
\text { Science: DID coefficient }-0.096, p>0.10^{\mathrm{T} 0}[32]\end{array}$ \\
\hline Wheezing & $\begin{array}{c}\text { Odds ratio: } 1.26, p=0.087 \text { [21] } \\
\text { among } 45+\text { years odds ratio: } 1.41,95 \% \text { CI: } 0.39,5.13 \text { [21] }\end{array}$ \\
\hline Any breathing difficulty & Odds ratio: $1.17, p=0.022[21]$ \\
\hline General health & Age-adjusted mean $\Delta:-0.061, p<0.01[23]$ \\
\hline Blood pressure & Age-adjusted mean $\Delta:-0.030, p>0.10[23]$ \\
\hline Pulse pressure & Age-adjusted mean $\Delta: 0.939, p<0.01[23]$ \\
\hline Hemoglobin level & $\begin{array}{c}\text { Age-adjusted mean } \Delta:-0.054, p<0.10[23] \\
\text { Age-adjusted mean } \Delta:-0.050, p>0.10^{\mathrm{T} 1}[30]\end{array}$ \\
\hline Risk of slow-healing wounds & Age-adjusted mean $\Delta: 0.047, p<0.01[23]$ \\
\hline Chest pain & Age-adjusted mean $\Delta: 0.088, p<0.05[23]$ \\
\hline \multirow[t]{3}{*}{ Under-five mortality rate } & Hazard ratio: $1.37, p=0.03^{\mathrm{T} 0}[12]$ \\
\hline & Hazard ratio: $1.33, p=0.01^{\mathrm{T} 1}[12]$ \\
\hline & Hazard ratio: $1.25, p=0.05^{\mathrm{T} 2}[12]$ \\
\hline Mortality under one day & Age-adjusted mean $\Delta: 0.005, p>0.10^{\mathrm{T} 1}[30]$ \\
\hline Mortality under three months & Age-adjusted mean $\Delta: 0.021, p<0.05^{\mathrm{T} 1}[30]$ \\
\hline Mortality under one year & Age-adjusted mean $\Delta: 0.027, p<0.05^{\mathrm{T} 1}[30]$ \\
\hline \multicolumn{2}{|l|}{ Economic outcomes } \\
\hline Earnings & $\begin{array}{c}\Delta:-0.042,95 \% \text { CI: }-0.180,0.097[24] \\
\text { DID coefficient: }-0.017, p>0.10^{\mathrm{T} 0}[33]\end{array}$ \\
\hline
\end{tabular}


Table 2. Cont.

\begin{tabular}{cc}
\hline Outcome Measures among Exposed Group & Study Results \\
\hline Annual salary & DID coefficient: $-0.012, p>0.10^{\mathrm{T} 0}[33]$ \\
\hline Home ownership & DID coefficient: $-0.026 p=0.027^{\mathrm{T} 0}[34]$ \\
\hline Employment & $\begin{array}{c}\text { Regression coefficient: }-0.026, p<0.05^{\mathrm{T} 3}[33] \\
\text { Regression coefficient: } 0.000, p>0.10^{\mathrm{T} 0}[34]\end{array}$ \\
\hline Hours worked & $\begin{array}{c}\Delta:-0.075,95 \% \mathrm{CI}:-0.145,-0.016[24] \\
\Delta:-4.7 \%, p<0.05[25]\end{array}$ \\
\hline Self-employed & DID coefficient: $0.007, p>0.10^{\mathrm{T} 0}[33]$ \\
\hline Child labor & $\Delta: 0.032, p<0.05[25]$ \\
\hline Currently enrolled in a school & $\Delta: 0.039, p<0.05[25]$ \\
\hline Graduated primary school & Age-adjusted mean $\Delta: 0.024, p>0.10^{\mathrm{T} 1}[30]$ \\
\hline $\begin{array}{c}\text { T0 }: \text { Exposed to Ramadan during conception; }{ }^{\mathrm{T} 1}: \text { Exposed to Ramadan in trimester 1; }{ }^{\mathrm{T} 2}: \text { Exposed to Ramadan in trimester 2; } \\
\text { Ramadan in trimester 3. }\end{array}$ & Age-adjusted mean $\Delta: 0.048, p>0.10^{\mathrm{T} 1}[30]$
\end{tabular}

In comparison with non-exposed Muslims, the risk of experiencing a symptom of any breathing difficulty (wheezing, shortness of breath) or being diagnosed with a lung disease (asthma or other lung condition) was higher among exposed Muslims. Wheezing prevalence was also higher among exposed adult Muslims living in Muslim areas and the association tended to increase with age, being strongest among those aged 45 years or older [21]. Exposure to Ramadan fasting before birth was associated with poorer general health, increased risk of slow-healing wounds, and chest pain (symptom indicative of diabetes and coronary heart disease). On average, exposed Muslims had a higher pulse pressure than non-exposed Muslims [23].

\subsection{Economic Outcomes}

Investigating health and economic consequences of in utero Ramadan exposure, one study showed that men exposed during first month of gestation were less likely to own a home when compared with non-Muslims [34]. In a Caribbean study, adults aged between 24 and 55 had a lower likelihood of employment if they were exposed to Ramadan around the seventh month of gestation in comparison with non-Muslims [33]. In Indonesia, a significant reduction in hours worked was found among exposed females aged 18-65 years. No significant findings were observed among exposed adult males [24]. Similarly, another study showed that children exposed to Ramadan in utero performed more child labor, and exposed adults worked fewer hours per week and were more likely to be self-employed than unexposed adults [25].

Several health and economic outcomes presented in Table 2 and described above indicate that being exposed to the month of Ramadan during conception or the first trimester of gestation was associated with higher under-five mortality rate [12], higher mortality under three months and under one year [30], shorter stature [26], lower body mass index [26], increased incidence of vision, hearing and learning disabilities [34], lower mathematics, writing and reading scores [31], as well as being less likely to own a home [34].

\section{Discussion}

The 16 available studies for this systematic review suggest that in utero Ramadan exposure may have negative long-term consequences on health and economic outcomes. Some negative effects were particularly observed when Ramadan occurred during conception or the first trimester of the pregnancy. Findings also suggest that the age at which the outcome is measured $[21,26]$ and sex $[24,35]$ may play important roles. These results are in line with the fetal programming theory, where during the first trimester, the fetus is in its most vulnerable state and particularly prone to negative effects from the surrounding envi- 
ronment. These effects are expected to manifest at post-reproductive age [21]. The strongest effects may also be due to higher fasting rates in early pregnancy, which survey-based studies have reported $[36,37]$.

The British Islamic Medical Association has published a compendium of evidence on Ramadan fasting, and recommends avoiding Ramadan fasting in the first trimester, or intermittent fasting if the pregnant women are very keen to fast. Fasting in the second and third trimester of pregnancy seems to be relatively safe in healthy women (low/moderate-risk category). However, women with underlying health conditions should be fully assessed by a qualified healthcare professional to evaluate and categorize their level of risk (moderate/high/very high). Those in the very-high-risk group must not fast, and those in the high-risk group should be discouraged from fasting [38].

This systematic literature review is, to the best of our knowledge, the first to assess the available scientific knowledge about the long-term effects of in utero Ramadan exposure on health and economic outcomes. Even though almost all studies show small negative effects, it is difficult to generalize these findings due to a number of reasons: although we used a broad search strategy, we found few published studies, and these studies looked at many different outcomes. Therefore, we were neither able to perform a meta-analysis to strengthen the evidence, nor were we able to systematically tackle the possibility of publication bias. However, 13 out of 16 (81\%) of our studies had samples over 10,000; thus, the case of included small studies being more likely to be "negative" may not be an issue in this work.

Another limitation is the retrospective nature of the studies. Prospective studies assessing Ramadan exposure more objectively are needed. Given the design of most studies using date of birth as the only indicator to define the in utero Ramadan exposure (intention-to-treat design), it remains unclear if the observed effects are due to Ramadan fasting itself or due to behavioral changes or any other event strictly related to Ramadan. Usually defining the exposure by date of birth tries to take into account some variability in the length of pregnancy by additional categorization with different cut-off values; however, it remains a limitation [23]. Furthermore, only one study directly assessed the fasting adherence of mothers. Therefore, pregnant women should also pay attention to the quality of their diet, stress levels, and sleep schedule during Ramadan [39]. The intention-to-treat design is prone to nondifferential misclassification and underestimates the real strength of the associations [12,21]. It has the benefits of the easy utilization of population-wide datasets for analysis, avoiding confounding due to non-random dropouts. Studies directly comparing Muslims and non-Muslims are prone to confounding, because over time, there may be considerable factors associated with the disease and with being a Muslim. The included studies mostly adjusted for age, sex, and month of birth.

\section{Conclusions}

In conclusion, this systematic literature review found limited evidence that, in line with the biological hypothesis, in utero Ramadan exposure may adversely impact longterm health and economic well-being. In some regions, up to $90 \%$ of pregnant Muslims practice Ramadan fasting [9], and in each generation, the global estimated number of up to 535 million babies are exposed to Ramadan in utero [13]; therefore, we highly encourage public health researchers to further explore possible impacts of in utero Ramadan exposure.

The aspirations of pregnant Muslim women who want to fast during Ramadan should be respected. At the same time, awareness of the potential risks of Ramadan fasting during pregnancy needs to be raised among pregnant women, equally with the risk of gestational diabetes mellitus and other fetal-maternal risks [40]. Clinicians and other antenatal care workers should promote better maternal healthcare to help manage a healthy pregnancy and reduce negative effects for their offspring [26].

On an individual level, disadvantageous consequences are likely to be relatively small compared to risk behavior, or may possibly even be due to bias. However, even small effect sizes are important from a public health perspective. Further research utilizing longitudinal 
data from the wider Muslim population is needed to generate clear scientific evidence and to determine the possible effects of in utero Ramadan exposure with respect to the three trimesters, the duration of the exposure, and the underlying cause. Thus, well-designed studies investigating Ramadan exposure during pregnancy are needed to investigate the full impacts on offspring.

Supplementary Materials: The following are available online at https://www.mdpi.com/article/ 10.3390/nu13124511/s1, Table S1: Full search strategy for all databases, Table S2: Quality assessment of included studies using the Specialist Unit for Review Evidence (SURE) checklist, Table S3: PRISMA checklist.

Author Contributions: Conceptualization: M.R.M., V.W.; methodology: A.S.W., A.D., K.A., O.H., P.D. and S.K.; literature search and data analysis: M.R.M. and E.A; Writing-Original draft preparation: M.R.M.; writing—review and editing: E.A., A.S.W., A.D., K.A., O.H., P.D., S.K. and V.W.; visualization: M.R.M. and V.W.; supervision: V.W.; funding acquisition: M.R.M. All authors have read and agreed to the published version of the manuscript.

Funding: This work was supported by Deutscher Akademischer Austauschdienst (DAAD)/German Academic Exchange Service Research Grants-Doctoral Programmes in Germany, 2019/2020; grant number: 57440921.

Institutional Review Board Statement: Not applicable.

Informed Consent Statement: Not applicable.

Data Availability Statement: All literature reviewed in the study was publicly available.

Conflicts of Interest: The authors declare no conflict of interest. The funders had no role in the design of the study; in the collection, analyses, or interpretation of data; in the writing of the manuscript, or in the decision to publish the results.

\section{References}

1. Leiper, J.B.; Molla, A.M.; Molla, A.M. Effects on health of fluid restriction during fasting in Ramadan. Eur. J. Clin. Nutr. 2003, 57, S30-S38. [CrossRef] [PubMed]

2. Seiermann, A.U.; Al-Mufti, H.; Waid, J.L.; Wendt, A.S.; Sobhan, S.; Gabrysch, S. Women's fasting habits and dietary diversity during Ramadan in rural Bangladesh. Matern. Child Nutr. 2021, 17, e13135. [CrossRef] [PubMed]

3. Mazidi, M.; Rezaie, P.; Chaudhri, O.; Karimi, E.; Nematy, M. The effect of Ramadan fasting on cardiometabolic risk factors and anthropometrics parameters: A systematic review. Pak. J. Med. Sci. 2015, 31, 1250-1255. [CrossRef] [PubMed]

4. Kul, S.; Savaş, E.; Öztürk, Z.A.; Karadă̆, G. Does Ramadan Fasting Alter Body Weight and Blood Lipids and Fasting Blood Glucose in a Healthy Population? A Meta-analysis. J. Relig. Health 2014, 53, 929-942. [CrossRef]

5. Kadri, N.; Tilane, A.; El Batal, M.; Taltit, Y.; Tahiri, S.M.; Moussaoui, D. Irritability during the month of Ramadan. Psychosom. Med. 2000, 62, 280-285. [CrossRef]

6. Rouhani, M.H.; Azadbakht, L. Is Ramadan fasting related to health outcomes? A review on the related evidence. J. Res. Med. Sci. 2014, 19, 987-992.

7. Ghazal, K.; Khazaal, J.; Chahine, R.; Hajjar, C.; El Hasan, J.; Naser, L.; Koulaymi, E.; Yared, G. Ramadan fasting during pregnancy: Characteristics and outcomes. Int. J. Reprod. Contracept. Obstet. Gynecol. 2020, 9, 3936-3943. [CrossRef]

8. Joosoph, J.; Abu, J.; Yu, S.L. A survey of fasting during pregnancy. Singap. Med. J. 2004, 45, 583-586.

9. Baynouna Al Ketbi, L.M.; Niglekerke, N.J; Zein Al Deen, S.M.; Mirghani, H. Diet restriction in Ramadan and the effect of fasting on glucose levels in pregnancy. BMC Res. Notes 2014, 7, 392. [CrossRef]

10. Hayward, A.R. The human fetus and newborn: Development of the immune response. Birth Defects Orig. Artic. Ser. 1983, 19, 289-294.

11. Palmer, A.C. Nutritionally mediated programming of the developing immune system. Adv. Nutr. Bethesda Md. 2011, 2, 377-395. [CrossRef]

12. Schoeps, A.; van Ewijk, R.; Kynast-Wolf, G.; Nebié, E.; Zabré, P.; Sié, A.; Gabrysch, S. Ramadan exposure in utero and child mortality in Burkina Faso: Analysis of a population-based cohort including 41,025 children. Am. J. Epidemiol. 2018, 187, 2085-2092. [CrossRef]

13. Glazier, J.D.; Hayes, D.J.L.; Hussain, S.; D'Souza, S.W.; Whitcombe, J.; Heazell, A.E.P.; Ashton, N. The effect of Ramadan fasting during pregnancy on perinatal outcomes: A systematic review and meta-analysis. BMC Pregnancy Childbirth 2018, 18, 421. [CrossRef]

14. Oosterwijk, V.N.L.; Molenaar, J.M.; van Bilsen, L.A.; Kiefte-de Jong, J.C. Ramadan Fasting during Pregnancy and Health Outcomes in Offspring: A Systematic Review. Nutrients 2021, 13, 3450. [CrossRef] 
15. Roseboom, T.; de Rooij, S.; Painter, R. The Dutch famine and its long-term consequences for adult health. Early Hum. Dev. 2006, 82, 485-491. [CrossRef]

16. Painter, R.C.; de Rooij, S.R.; Bossuyt, P.M.; Simmers, T.A.; Osmond, C.; Barker, D.J.; Bleker, O.P.; Roseboom, T.J. Early onset of coronary artery disease after prenatal exposure to the Dutch famine. Am. J. Clin. Nutr. 2006, 84, 322-327. [CrossRef]

17. De Rooij, S.R.; Wouters, H.; Yonker, J.E.; Painter, R.C.; Roseboom, T.J. Prenatal undernutrition and cognitive function in late adulthood. Proc. Natl. Acad. Sci. USA 2010, 107, 16881-16886. [CrossRef]

18. Moher, D.; Liberati, A.; Tetzlaff, J.; Altman, D.G.; Group, P. Preferred reporting items for systematic reviews and meta-analyses: The PRISMA statement. PLoS Med. 2009, 6, e1000097. [CrossRef]

19. CPH's Data Extraction and Assessment Template. Available online: https://ph.cochrane.org/review-authors (accessed on 21 November 2021).

20. Specialist Unit for Review Evidence (SURE). Available online: https://www.cardiff.ac.uk/_data/assets/pdf_file/0006/1142997 /SURE-CA-form-for-Cohort_2018.pdf (accessed on 23 November 2021).

21. Pradella, F.; van Ewijk, R. As Long as the Breath Lasts: In Utero Exposure to Ramadan and the Occurrence of Wheezing in Adulthood. Am. J. Epidemiol. 2018, 187, 2100-2108. [CrossRef]

22. Van Ewijk, R.J.; Painter, R.C.; Roseboom, T.J. Associations of prenatal exposure to Ramadan with small stature and thinness in adulthood: Results from a large Indonesian population-based study. Am. J. Epidemiol. 2013, 177, 729-736. [CrossRef]

23. Van Ewijk, R. Long-term health effects on the next generation of Ramadan fasting during pregnancy. J. Health Econ. 2011, 30, 1246-1260. [CrossRef]

24. Majid, F.; Behrman, J.; Mani, S. Short-term and long-term distributional consequences of prenatal malnutrition and stress: Using Ramadan as a natural experiment. BMJ Glob. Health 2019, 4, e001185. [CrossRef]

25. Majid, M.F. The persistent effects of in utero nutrition shocks over the life cycle: Evidence from Ramadan fasting. J. Dev. Econ. 2015, 117, 48-57. [CrossRef]

26. Kunto, Y.S.; Mandemakers, J.J. The effects of prenatal exposure to Ramadan on stature during childhood and adolescence: Evidence from the Indonesian Family Life Survey. J. Econ. Hum. Biol. 2019, 33, 29-39. [CrossRef]

27. Chaudhry, T.T.; Mir, A. The Impact of Prenatal Exposure to Ramadan on Child Anthropomorphic Outcomes in Pakistan. Matern. Child Health J. 2021, 25, 1136-1146. [CrossRef]

28. Azizi, F.; Sadeghipour, H.; Siahkolah, B.; Rezaei-Ghaleh, N. Intellectual development of children born of mothers who fasted in Ramadan during pregnancy. Int. J. Vitam. Nutr. Res. 2004, 74, 374-380. [CrossRef]

29. Karimi, S.M.; Little, B.B.; Mokhtari, M. Short-term fetal nutritional stress and long-term health: Child height. Am. J. Hum. Biol. 2021, 33, e23531. [CrossRef]

30. Lee, S.; Nam, M.; Jeong, D.; Lee, W. Does Ramadan Harm Infant Health? Evidence from Ethiopia. Int. Econ. J. 2020, 34, 613-633. [CrossRef]

31. Almond, D.; Mazumder, B.; Van Ewijk, R. Fasting during Pregnancy and Children's Academic Performance; 0898-2937; National Bureau of Economic Research: Cambridge, MA, USA, 2011.

32. Greve, J.; Schultz-Nielsen, M.L.; Tekin, E. Fetal malnutrition and academic success: Evidence from Muslim immigrants in Denmark. J. Econ. Educ. Rev. 2017, 60, 20-35. [CrossRef]

33. Schultz-Nielsen, M.L.; Tekin, E.; Greve, J. Labor market effects of intrauterine exposure to nutritional deficiency: Evidence from administrative data on Muslim immigrants in Denmark. Econ. Hum. Biol. 2016, 21, 196-209. [CrossRef]

34. Almond, D.; Mazumder, B. Health capital and the prenatal environment: The effect of Ramadan observance during pregnancy. Am. Econ. J. Appl. Econ. 2011, 3, 56-85. [CrossRef]

35. Karimi, S.M.; Basu, A. The effect of prenatal exposure to Ramadan on children's height. Econ. Hum. Biol. 2018, 30, 69-83. [CrossRef] [PubMed]

36. Van Bilsen, L.A.; Savitri, A.I.; Amelia, D.; Baharuddin, M.; Grobbee, D.E.; Uiterwaal, C.S.P.M. Predictors of Ramadan fasting during pregnancy. J. Epidemiol. Glob. Health 2016, 6, 267-275. [CrossRef] [PubMed]

37. Ziaee, V.; Kihanidoost, Z.; Younesian, M.; Akhavirad, M.-B.; Bateni, F.; Kazemianfar, Z.; Hantoushzadeh, S. The effect of ramadan fasting on outcome of pregnancy. Iran. J. Pediatr. 2010, 20, 181-186. [PubMed]

38. BIMA. Ramadan Compendium. Available online: https:/ / britishima.org/ramadan/compendium/ (accessed on 22 November 2021).

39. Seiermann, A.U.; Gabrysch, S. Ramadan Is Not the Same As Ramadan Fasting. J. Nutr. 2020, 150, 968. [CrossRef] [PubMed]

40. Quaresima, P.; Visconti, F.; Interlandi, F.; Puccio, L.; Caroleo, P.; Amendola, G.; Morelli, M.; Venturella, R.; Di Carlo, C. Awareness of gestational diabetes mellitus foetal-maternal risks: An Italian cohort study on pregnant women. BMC Pregnancy Childbirth 2021, 21, 692. [CrossRef] [PubMed] 